\title{
TAF11 Gene
}

National Cancer Institute

\section{Source}

National Cancer Institute. TAF11 Gene. NCI Thesaurus. Code C20540.

This gene plays a role in transcriptional initiation and signal transduction modulation. 